\title{
Enzymes of the AKR1B and AKR1C subfamilies and uterine diseases
}

\author{
Tea Lanišnik Rižner * \\ Faculty of Medicine, Institute of Biochemistry, University of Ljubljana, Ljubljana, Slovenia
}

Edited by:

Yi Jin, University of Pennsylvania, USA

Reviewed by:

Wei Ni, Michigan State University, USA

Roland Seifert, Medical School of

Hannover, Germany

*Correspondence:

Tea Lanišnik Rižner, Faculty of

Medicine, Institute of Biochemistry,

University of Ljubljana, Vrazov trg 2,

1000 Ljubljana, Slovenia.

e-mail: tea.lanisnik-rizner@mf.uni-lj.si
Endometrial and cervical cancers, uterine myoma, and endometriosis are very common uterine diseases. Worldwide, more than 800,000 women are affected annually by gynecological cancers, as a result of which, more than 360,000 die. During their reproductive age, about $70 \%$ of women develop uterine myomas and 10-15\% suffer from endometriosis. Uterine diseases are associated with aberrant inflammatory responses and concomitant increased production of prostaglandins (PG). They are also related to decreased differentiation, due to low levels of protective progesterone and retinoic acid, and to enhanced proliferation, due to high local concentrations of estrogens. The pathogenesis of these diseases can thus be attributed to disturbed PG, estrogen, and retinoid metabolism and actions. Five human members of the aldo-keto reductase 1B (AKR1B) and $1 \mathrm{C}$ (AKR1C) superfamilies, i.e., AKR1B1, AKR1B10, AKR1C1, AKR1C2, and AKR1C3, have roles in these processes and can thus be implicated in uterine diseases. AKR1B1 and AKR1C3 catalyze the formation of PGF2 $\alpha$, which stimulates cell proliferation. AKR1C3 converts PGD2 to $9 \alpha, 11 \beta$-PGF2, and thus counteracts the formation of 15-deoxy-PGJ2, which can activate pro-apoptotic peroxisome-proliferator-activated receptor $\gamma$. AKR1B10 catalyzes the reduction of retinal to retinol, and thus lessens the formation of retinoic acid, with potential pro-differentiating actions. The AKR1C1-AKR1C3 enzymes also act as 17-keto- and 20ketosteroid reductases to varying extents, and are implicated in increased estradiol and decreased progesterone levels. This review comprises an introduction to uterine diseases and $A K R 1 B$ and AKR1C enzymes, followed by an overview of the current literature on the $A K R 1 B$ and $A K R 1 C$ expression in the uterus and in uterine diseases. The potential implications of the AKR1B and AKR1C enzymes in the pathophysiologies are then discussed, followed by conclusions and future perspectives.

Keywords: endometrial cancer, cervical cancer, endometriosis, uterine myoma, endometriosis, prostaglandins, estrogens, retinoids

\section{UTERINE DISEASES}

Uterine diseases include malignant diseases, such as endometrial cancer and cervical cancer, and benign diseases, which include mainly uterine myoma (myoma uteri, uterus myomatosus) and endometriosis.

\section{ENDOMETRIAL CANCER}

Endometrial cancer is the fourth-most-common cancer in Europe and the sixth-most-common cancer worldwide, with the majority of cases arising in post-menopausal women (Ferlay et al., 2008). For 2010, 303,071 new cases and 77,671 deaths were estimated

\footnotetext{
Abbreviations: $5 \alpha$-DHP, $5 \alpha$-dihydroprogesterone; ADH, alcohol dehydrogenase; AKR, aldo-keto reductase; ALDH, aldehyde dehydrogenase; AP1, activator protein 1; COX-2, cycloxygenase-2; FA, farnesoic acid; FAL, farnesal; FOH, farnesol; FT, farnesyltranserase; GABA, $\gamma$-aminobutyric acid; GGA, geranylgeranoic acid; GGAL, geranylgeranial; GGOH, geranylgeranyol; GGT, geranylgeranyltransferase; GTPases, guanine nucleotide triphosphatases; IL, interleukin; MAPK, mitogen-activated protein kinase; NF-кB, nuclear factor kappa-light-chain-enhancer of activated $\mathrm{B}$ cells; PCLY, prenylcystein lyase; PG, prostaglandin; PKC, protein kinase C; PLC, phospholiase C; PPAR $\gamma$, peroxisome-proliferator-activated receptor $\gamma$; RARs, retinoic acid receptors; RXRs, retinoid X receptors; TNF, tumor necrosis factor.
}

(Ferlay et al., 2008). Most endometrial cancers are sporadic and only 10\% of cases are familiar (Amant et al., 2005; Ryan et al., 2005). The sporadic cases can be divided into two subgroups: type 1 , the estrogen-dependent endometrioid carcinomas (80\%); and type 2 , the poorly differentiated, more aggressive form, which is considered to be estrogen independent (20\%; Inoue, 2001). Type 1 endometrial cancer is related to exposure to estrogens (of endogenous or exogenous origins) that is not opposed by progesterone or synthetic progestins. This exposure increases the mitotic activity of endometrial cells, along with the number of DNA replication errors and can lead to somatic mutations that result in a malignant phenotype (Inoue, 2001). Development of endometrial cancer is also associated with a number of risk factors, such as obesity, nulliparity, early age at menarche, late onset of menopause, among others (Wallace et al., 2010). In the last few years, it has also been suggested that inflammation contributes to the initiation and progression of endometrial cancer (Wallace et al., 2010). The prostaglandins (PGs) are mediators of inflammation, and they have important roles in the pathogenesis of endometrial cancer. PGE2 and PGF2 $\alpha$ are formed locally in cancerous endometrium, where in autocrine/paracrine manners, they can stimulate cell 
proliferation, cell adhesion, cell migration, and angiogenesis (Sales et al., 2005, 2008; Wallace et al., 2010).

\section{CERVICAL CANCER}

Cervical cancer is the seventh-most-common cancer in women in Europe and the third-most-common cancer worldwide. The majority of cases are detected in developing countries, where it accounts for $13 \%$ of all female cancers (Ferlay et al., 2008). For 2010,553,119 new cases, and 288,109 deaths were estimated as due to cervical cancer (Ferlay et al., 2008). The average age at onset is $45-55$ years. The pathology of cervical cancer is related to infection with human papillomavirus (HPV) the DNA of which has been detected in $90 \%$ of cervical cancer cases (reviewed in Faridi et al., 2011). HPV, especially high-risk HPV16 and HPV18, are the vectors that confer susceptibility to neoplastic conversion or that directly induce malignant phenotypes in the infected epithelial cells by their oncoproteins E6 and E7, which block the normal functions of the tumor suppressor genes p53 and the retinoblastoma protein (pRb; reviewed in Faridi et al., 2011). Cervical cancer is also related to chronic inflammation of the cervix, due to cellular and molecular changes that can be triggered by human semen, which increase the concentration of cytokines and chemokines. Higher levels of PGE2 are considered as possible promoters of cervical carinogenesis (Herfs et al., 2009). Some studies have shown that risk of cervical cancer increases with use of oral contraceptives, and recently it has been reported that estrogens can promote HPV-induced carcinogenesis (Chung et al., 2010).

\section{UTERINE MYOMAS}

Uterine myomas are also known as leiomyomas or uterine fibroids (myoma uteri or uterus myomatosus). These are benign tumors of the myometrium that occur in up to $70 \%$ of women of reproductive age (Maybin et al., 2011). As such, they are the most common tumors of women of reproductive age, although they have clinically significant symptoms in only one-third of the affected population (Miller, 2008). The majority of cases are thus asymptomatic; when symptomatic, these myomas can be linked to heavy menstrual bleeding, anemia, and even pregnancy complications, which can include difficulty conceiving and increased risk of miscarriage (Miller, 2008). Myomas appear after menarche and decline after menopause, which implicates estrogens as the primary factor that drive their growth. The pathophysiology of uterine myomas is far from clear. At the molecular level, several pathways were associated with this disease, including the retinoic-acid pathway, growth-factor signaling, and extracellularmatrix formation (Zaitseva et al., 2007). Recently, myomas have also been related to aberrant inflammation (Maybin et al., 2011).

\section{ENDOMETRIOSIS}

Endometriosis is a complex, estrogen-dependent disease that is defined as the presence of endometrial glands and stroma outside the uterine cavity (Giudice and Kao, 2004). It is diagnosed mainly in women of reproductive age, and estimates show that up to $15 \%$ of all pre-menopausal women, and $35-50 \%$ of women with infertility and pelvic pain are affected (Giudice and Kao, 2004). Ectopic endometrial tissue can be found in different parts of peritoneal cavity, thus forming three different entities: ovarian, peritoneal, and deep infiltrative endometriosis (Nisolle and
Donnez, 1997). The pathogenesis of endometriosis is very complex and remains not completely understood. The most widely accepted is the theory on retrograde menstruation and disturbed immune system (Berkley et al., 2005). However, the pathogenesis also involves changes in apoptosis, cell adhesion, degradation of the extracellular matrix, angiogenesis, cell communication, loss of differentiation capacity (Hompes and Mijatovic, 2007), as well as alterations in other biological pathways (Giudice and Kao, 2004). Also environmental factors, increased local formation of estradiol, and diminished progesterone action affect the development of endometriosis (Giudice and Kao, 2004; Berkley et al., 2005). Enhanced inflammation has been seen in eutopic endometrium of endometriosis patients, and growth of the endometrium in ectopic sites leads to chronic pelvic inflammatory responses, as supported by the increased concentrations of PGE2 and PGF2 $\alpha$ in the peritoneal fluid of endometriosis patients (Banu et al., 2009; Lousse et al., 2010). PGE2 regulates proliferation of endometriotic cells, immune suppression, and angiogenesis (Wu, 2005; Wu et al., 2007, 2010), while both PGE2 and PGF2 $\alpha$ promote transcription of angiogenic factors, such as vascular epithelial growth factor (Jabbour et al., 2006).

\section{THE ENZYMES OF THE AKR1B SUBFAMILY}

There are two well-characterized human members of the aldoketo reductase 1B (AKR1B) subfamily, AKR1B1 and AKR1B10. These AKR1B enzymes are known as aldose reductases, and they catalyze the reduction of aldehydes to alcohol (glucose to sorbitol in the polyol pathway, and retinal to retinol) and the reduction of a series of other substrates (Table 1; Penning and Drury, 2007; Barski et al., 2008).

AKR1B1 is the most studied of the AKRs. The reduction of glucose by AKR1B1 during hyperglycemia has been linked to the development of tissue injury associated with diabetes. Therefore, a number of AKR1B1 inhibitors have been developed for the treatment of diabetic complications (reviewed by Liu et al., 2009; Ramana, 2011; Srivastava et al., 2011; Tammali et al., 2011). In addition to reduction of glucose to sorbitol in the polyol pathway, AKR1B1 catalyzes the reduction of further substrates (Table 1), which include lipid peroxidation products, such as 4hydroxynonenal, and their glutathione (GSH) conjugates, with a higher catalytic efficiency reported for the latter (Barski et al., 2008; Kabututu et al., 2009; Ramana, 2011; Table 1). Recombinant AKR1B1 also acts as a PG synthase, as it can convert PGH2 into PGF2 $\alpha$ with a lower $K_{\mathrm{M}}$ and a higher $V_{\max }$ compared to AKR1C3 (Kabututu et al., 2009). As confirmed by gene silencing, transient transfection studies, and the use of specific inhibitors, AKR1B1 is a functional PGF2 $\alpha$ synthase (Bresson et al., 2011). Over the last few years, the involvement of AKR1B1 in inflammatory pathways has also been reported. By reducing GSH conjugated aldehydes, AKR1B1 indirectly stimulates NF- $\mathrm{KB}$, which can lead to activation of the inflammatory cytokines and the inflammatory mediators, such as cycloxygenase-2 (COX-2; Barski et al., 2008; Ramana, 2011; Figure 1). AKR1B1 has also been implicated in the development of human cancers, such as liver, breast, ovarian, and cervical cancers (reviewed by Alexiou et al., 2009). It is also associated with resistance toward anticancer drugs, such as the anthracycline antibiotic danorubicin, and cisplatin (Tammali et al., 2011). 
Table 1 | Kinetic parameters of the AKR1B1 and AKR1B10 enzymes.

\begin{tabular}{|c|c|c|c|c|c|c|c|}
\hline Substrate & \multicolumn{3}{|c|}{ AKR1B1 } & \multicolumn{3}{|c|}{ AKR1B10 } & References \\
\hline d,I-Glyceraldehyde & 65 & 33 & 507 & 563 & 29 & 52 & Shen et al. (2011) \\
\hline 4-Hydroxynonenal & 716 & 50 & 70 & 31 & 119 & 3,839 & Shen et al. (2011) \\
\hline GS-4-hydroxynonanal & 5 & 13 & 2,600 & ND & ND & ND & Shen et al. (2011) \\
\hline All-trans-retinol & NA & NA & NA & 0.4 & 4.3 & 12,750 & Ruiz et al. (2011a) \\
\hline 9-cis-retinal & ND & ND & ND & 0.7 & 0.9 & 1,300 & Ruiz et al. (2011a) \\
\hline PGH2 & 1.9 & 0.93 & 491 & ND & ND & ND & Kabututu et al. (2009) \\
\hline PGH2 & 29 & 6.06 & 210 & ND & ND & ND & Nagata et al. (2011) \\
\hline Farnesal & 37 & 27 & 730 & 2.5 & 23 & 9,100 & Endo et al. (2011) \\
\hline
\end{tabular}

$N A$, no activity; ND, not determined.

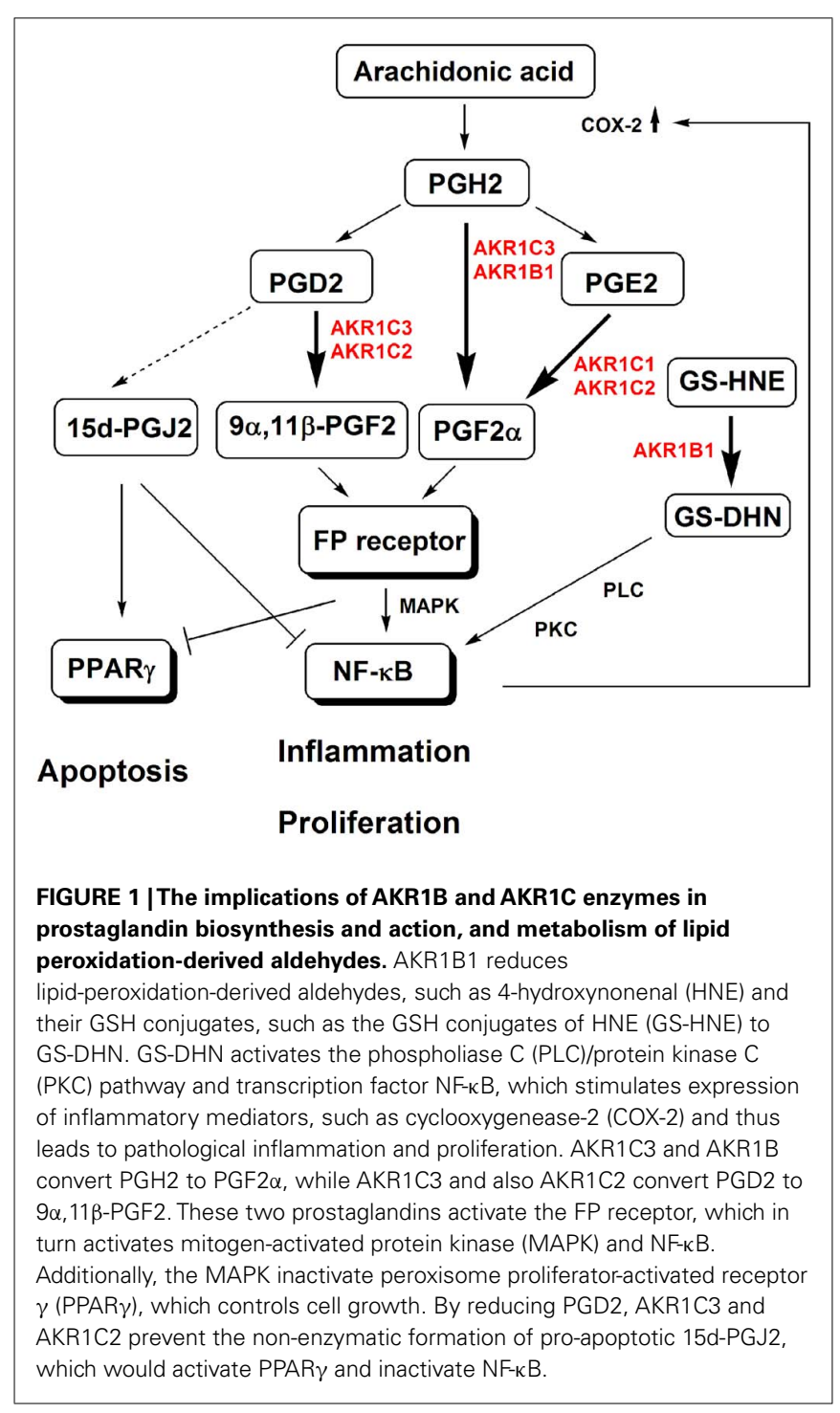

AKR1B10 has 71\% identical amino-acid residues to AKR1B1 and overlapping substrate specificities. With respect to retinols, AKR1B10 has a 100-fold higher catalytic efficiency toward alltrans-retinal, 9-cis-retinal, and 13-cis-retinal (Barski et al., 2008). AKR1B10 thus counteracts the formation of retinoic acid, a signaling molecule that is involved in the regulation of cell proliferation and differentiation. Similar to AKR1B1, AKR1B10 metabolizes the anticancer agents daunorubicin and idarubicin (Zhong et al., 2011). But in contrast to AKR1B1, which is ubiquitously expressed, AKR1B10 is expressed mainly in the small intestine and colon (Liu et al., 2011), and in different cancerous tissues (hepatocellular, lung, breast, colorectal, cervical, endometrial), although very weakly in normal tissues (Yoshitake et al., 2007). In colon carcinoma and lung carcinoma cells, AKR1B10 silencing induces apoptosis, decreases total phospholipids levels, and increases levels of reductive oxygen species and lipid peroxides (Wang et al., 2009). AKR1B10 also reduces isoprenyl aldehydes and is thus implicated in prenylation of small guanine nucleotide triphosphatases (GTPases) responsible for cell proliferation (Matsunaga et al., 2012; Novelli and D'Apice, 2012). This suggests that AKR1B10 represents an important cell-survival protein and also a novel drug target (Wang et al., 2009). The search for AKR1B10 inhibitors started recently and structurally diverse selective inhibitors of AKR1B10 have already been reported (Endo et al., 2010; Takemura et al., 2011; Soda et al., 2012). AKR1B10 is secreted from normal intestinal epithelium and cancer cell lines through a lysosome-mediated non-classical pathway, which suggests that it also represents a potential serum marker (Luo et al., 2011).

\section{THE AKR1B ENZYMES AND THE UTERUS}

The AKR1B1 protein is known to be widely expressed, and the published literature report its expression in normal endometrium and myometrium, where it is induced by IL-1 $\beta$ (Rossi et al., 2005), as well as in the cervix (Saraswat et al., 2006; Table 2). As AKR1B1 has a high catalytic efficiency as a PGF2 $\alpha$ synthase (Kabututu et al., 2009), it may be responsible for increased production of PGF2 $\alpha$ in the secretory as well as the menstrual phases of the 
Table 2 | Expression of $A K R 1 B 1$ and $A K R 1 B 10$ in human uterus.

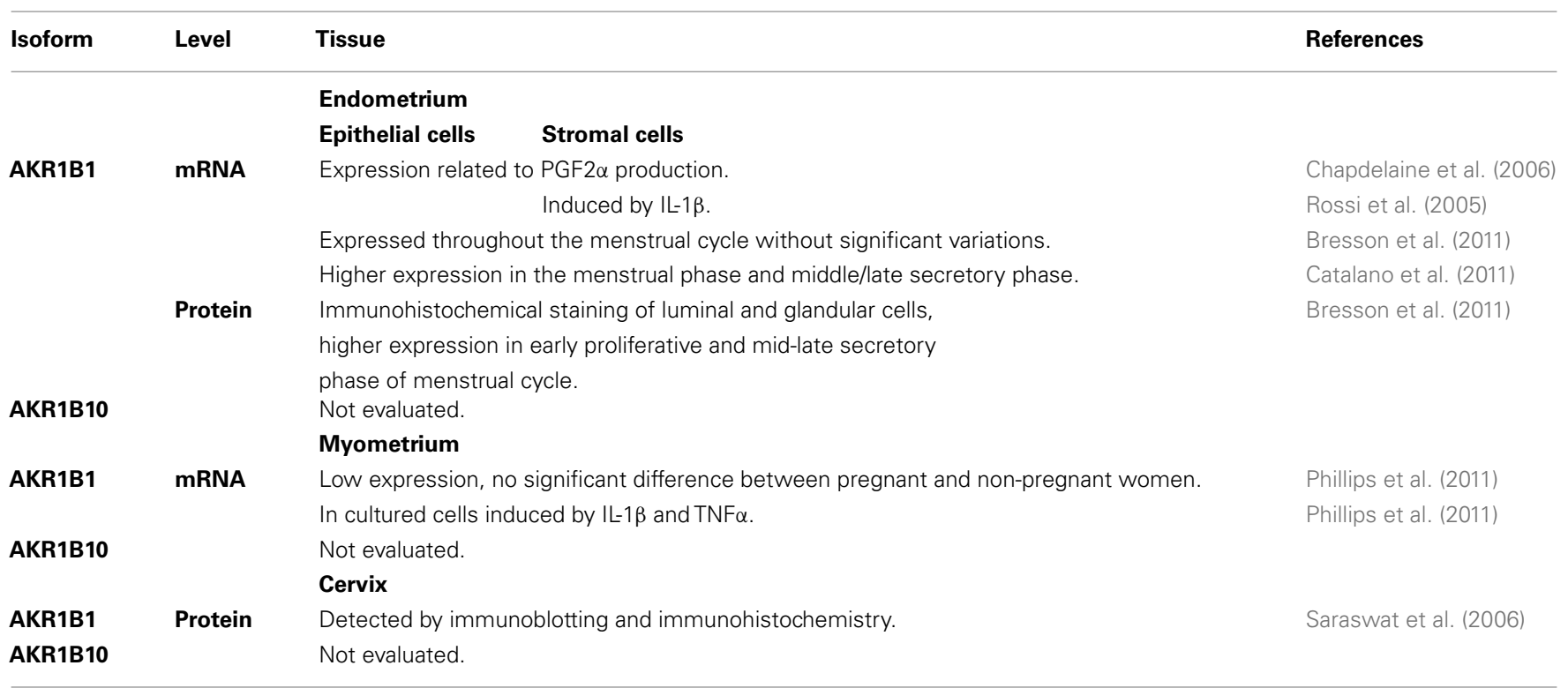

Table 3 | Expression of $A K R 1 B 1$ and $A K R 1 B 10$ in uterine diseases.

\begin{tabular}{lll}
\hline Isoform & Level & Tissue \\
\hline AKR1B1 & Endometrial cancer \\
AKR1B10 & Pot evaluated. & References \\
& & Staining in 16\% cases, 10\% to 20\% of cells in AKR1B10-positive cases. \\
& No correlation with age, clinical stage, pathological features, histological grade, \\
& metastasis, and recurrence after surgery. \\
& Cervical cancer \\
AKR1B1 & Protein & Detected in squamous cervical cancer and adenocarcinoma of the cervix, higher protein \\
& & levels, and enzymatic activity in cancer. \\
AKR1B10 & Staining in 20\% cases, 90\% of cells in AKR1B10-positive cases; correlates with tumor \\
& recurrence after surgery. \\
& Endometriosis \\
AKR1B1 & Not evaluated. \\
AKR1B10 & Not evaluated. \\
& Uterine myomas \\
AKR1B1 & Not evaluated. \\
AKR1B10 & Not evaluated.
\end{tabular}

menstrual cycle, when the highest concentrations of PGF2 $\alpha$ have been detected. Concurrently increased synthesis of PGF $2 \alpha$ and PGE2 in endometrium has important implications in menstruation. PGF $2 \alpha$ acts as a vasoconstrictor and induces myometrial contractions, while PGE2 acts as a vasodilator, which leads to increased edema (reviewed in Maybin et al., 2011). A significantly decreased ratio of PGF $2 \alpha /$ PGE2 was observed in women with heavy menstrual bleeding, which might be related to decreased expression/activity of AKR1B1 or increased expression/activity of PGE2 synthase in this condition (reviewed in Maybin et al., 2011). PGF $2 \alpha$ has been implicated in the development of primary dysmenorrhea, which again implies a role for AKR1B1 here (reviewed in Maybin et al., 2011). In contrast to AKR1B1, the expression of the $A K R 1 B 10$ gene in the endometrium, myometrium, and cervix of normal human uterus has not been reported.

\section{THE AKR1B ENZYMES IN ENDOMETRIAL AND CERVICAL CANCERS}

There have been no reports of the expression of $A K R 1 B 1$ in endometrial cancer, but AKR1B1 has been detected in squamous cervical cancer and adenocarcinoma of the cervix (Saraswat et al., 2006; Table 3). Increased AKR1B1 levels and increased activity detected in cervical cancer (Saraswat et al., 2006) may be related to its implication in inflammation, including its promotion of PGF2 $\alpha$ synthesis. It may also be associated with resistance to chemotherapeutics, which is a major problem in treatment of this disease. AKR1B10 has been revealed in cancerous endometrium 
and cervical cancer (Yoshitake et al., 2007; Table 3). In the later the expression correlated with tumor recurrence after surgery and the authors suggested that AKR1B10 represents a promising marker (Yoshitake et al., 2007). Similarly, as reported in lung cancer (Fukumoto et al., 2005), higher percentages of AKR1B10-positive cells were seen in squamous cell carcinoma (cervical cancer patients), as compared to adenocarcinoma (endometrial cancer patients; Yoshitake et al., 2007). AKR1B10 appears to be specific for this distinct morphology, where it might be associated with reduction of retinal to retinol, and thus with decreased levels of retinoic acid. This will remove the ligands for the retinoic acid receptors (RARs) and retinoid X receptors (RXRs), and thus prevent cell differentiation. At present, there appear to be no reports on the expression of AKR1B1 and AKR1B10 in uterine myomas or endometriosis.

\section{A POTENTIAL ROLE FOR THE AKR1B ENZYMES IN UTERINE DISEASES}

AKR1B1 has a relatively high catalytic efficiency as a PGF2 $\alpha$ synthase (Kabututu et al., 2009). PGF2 $\alpha$ acts through FP receptor and mitogen-activated protein kinase (MAPK) signaling, which activates NF- $\kappa \mathrm{B}$ and thus induces COX-2. Higher levels of COX-2 then lead to a further production of the PGs, and thus enhanced cell proliferation, cell adhesion, angiogenesis, and cytoskeleton remodeling of the endometrium (Figure 1; Sales et al., 2007, 2008). Additionally, AKR1B1 via reduction of the GSH conjugates of lipid-aldehydes stimulates transcription of various inflammatory cytokines, chemokines, and inflammatory mediators. Lipidperoxidation-derived aldehydes, such as 4-hydroxynonenal, are conjugated with GSH by GSH-S-transferase and reduced by AKR1B1 to the 1,4-dihydroxy-2-nonene GSH conjugate, which activates PLC, and also NF- $\kappa \mathrm{B}$ and $\mathrm{AP} 1$ via protein kinase $\mathrm{C}$ (PKC; Figure 1; Ramana, 2011). Furthermore, the cytokine IL-1 $\beta$ stimulates $A K R 1 B 1$ expression (Rossi et al., 2005), which may potentiate the activation of NF- $\kappa \mathrm{B}$ and may lead to a vicious inflammatory cycle. The uncontrolled inflammation is related to the development of uterine diseases, including endometrial cancer, uterine myoma, and endometriosis (Wallace et al., 2010; Maybin et al., 2011). As it is involved in inflammation via at least two possible mechanisms, AKR1B1 might also be involved in the pathogenesis of these diseases. To date, higher AKR1B1 expression has been reported only in cervical cancer (Saraswat et al., 2006) and there have been no reports of AKR1B1 expression in endometrial cancer, uterine myoma, and endometriosis. Endometriosis and endometrial cancer are associated with higher PGF $2 \alpha$ concentrations in peritoneal fluid and endometriosis tissue, and increased local formation of PGF $2 \alpha$ in cancer endometrium, respectively (Sales et al., 2008; Banu et al., 2009), thus AKR1B1 might be implicated in the pathogenesis of these diseases as well. In endometrial cancer cells, PGF2 $\alpha$ stimulates cell proliferation, cell adhesion, migration, and angiogenesis (Sales et al., 2008). Also, uterine myoma is related to aberrant inflammation, and thus AKR1B1 might also have a role in this disease.

Due to the high catalytic efficiency of AKR1B10 for the reduction of all-trans, 9-cis, and 13-cis retinaldehydes to retinols (Kabututu et al., 2009), the increased levels of AKR1B10 in endometrial and cervical cancer (Yoshitake et al., 2007) might be linked to depletion of retinoic acid. Decreased availability of the ligand for

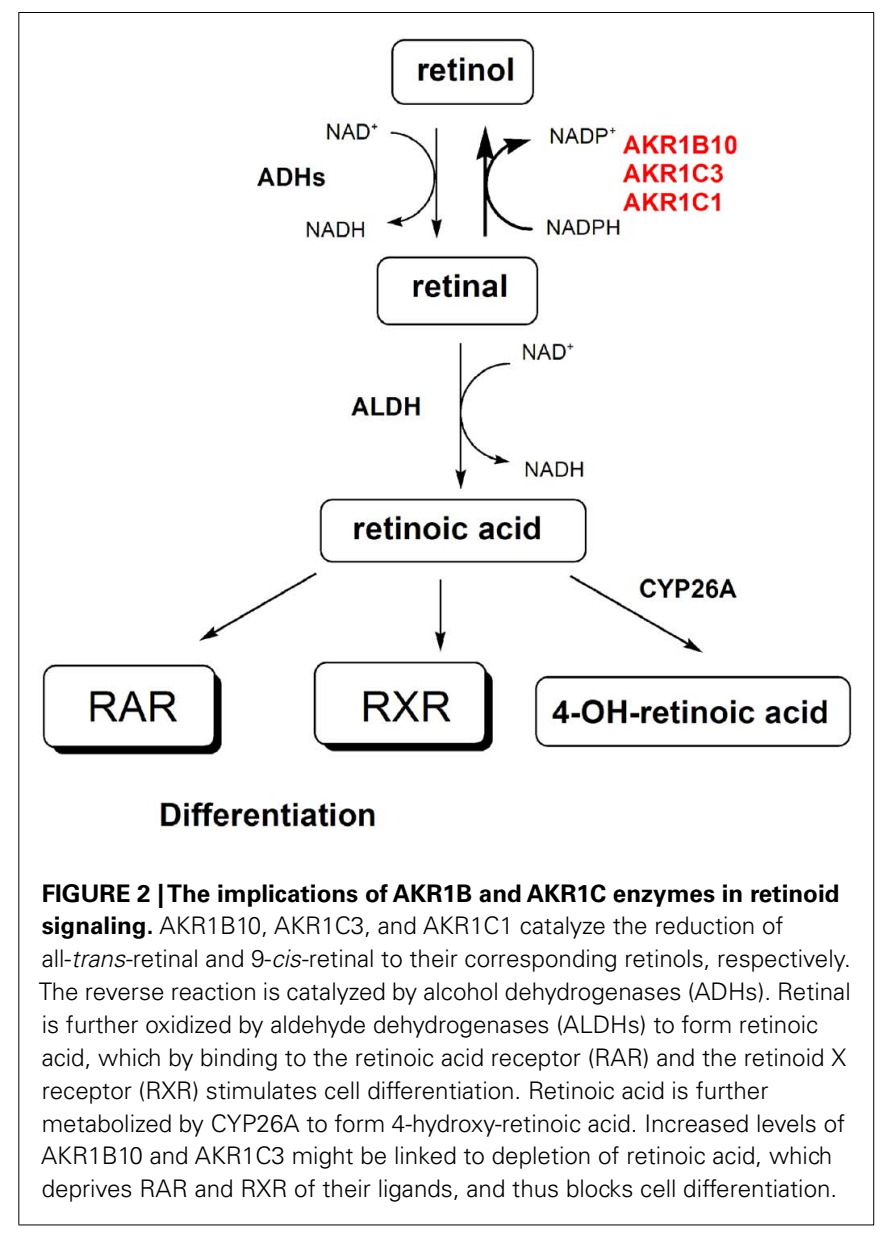

the RARs and RXRs, will lead to a loss of cell differentiation (Figure 2). The oxidation of retinal to retinoic acid by retinaldehyde dehydrogenase is irreversible in a cellular context, and reduction of retinals to retinols by AKR1B10 thus counteracts the synthesis of retinoic acid (Penning, 2005). Indeed retinoic acid and RAR agonists inhibit the growth of the Ishikawa endometrial cancer cell line (Tanabe et al., 2008; Cheng et al., 2011) and retinoic acid stimulates differentiation of the poorly differentiated CAC-1 endometrial adenocarcinoma cell line (Carter, 2003). Also, a very recent report on antitumor effects of inhibitors of the retinoic-acid-metabolizing CYP26A (Goss et al., 2011) confirmed the protective effects of retinoic acid and suggested that AKR1B10 inhibitors might have a similar role. Interestingly, topical retinoic acid has shown activity in cervical intraepithelial neoplasia (a potentially premalignant transformation of cervical cells; Abu et al., 2005), which implies a decreased protective effect of retinoic acid in precancerous tissue. However, in cervical cancer cell lines, no effects (in CaSki cells) and even stimulatory effect (in HeLa cells) of all-trans retinoic acid have been observed. As retinoic acid does not repress the expression of the viral oncoproteins E6 and E7 of HPV types 16 and 18, which have a major role in carcinogenesis of the cervix (Myga-Nowak et al., 2011), this shows that retinoids might have a role only in precancerous tissue.

Suppressed action of retinoic acid might also be related to the benign proliferative diseases, such as uterine myoma 
and endometriosis. Indeed, decreased expression of alcohol dehydrogenase 1 (ADH1) and aldehyde dehydrogenase 1 (ALDH1), which are responsible for the conversion of retinol to retinal and of retinal to retinoic acid, respectively, has been reported in uterine fibroids (Zaitseva et al., 2007). While decreased retinoid uptake, formation and action, and increased retinoicacid metabolism have been shown in endometriosis (Pavone et al., 2011). It has also been suggested that deficient retinoic-acid action in endometriosis leads to decreased levels of $17 \beta$-hydroxysteroid dehydrogenase type 2 , which converts the potent estradiol to the less active estrone. This leads to increased levels of the potent mitogen estradiol and thus increased cell proliferation (reviewed in Bulun, 2009). However, evaluation of the expression and role of AKRB10 in these diseases awaits further studies.

AKR1B10 has a high catalytic efficiency for reduction of isoprenyl aldehydes, farnesal (FAL), and geranylgeranial (GGAL; Endo et al., 2011) and is thus also involved in prenylation of cellular proteins (Figure 3). Proteins that undergo prenylation

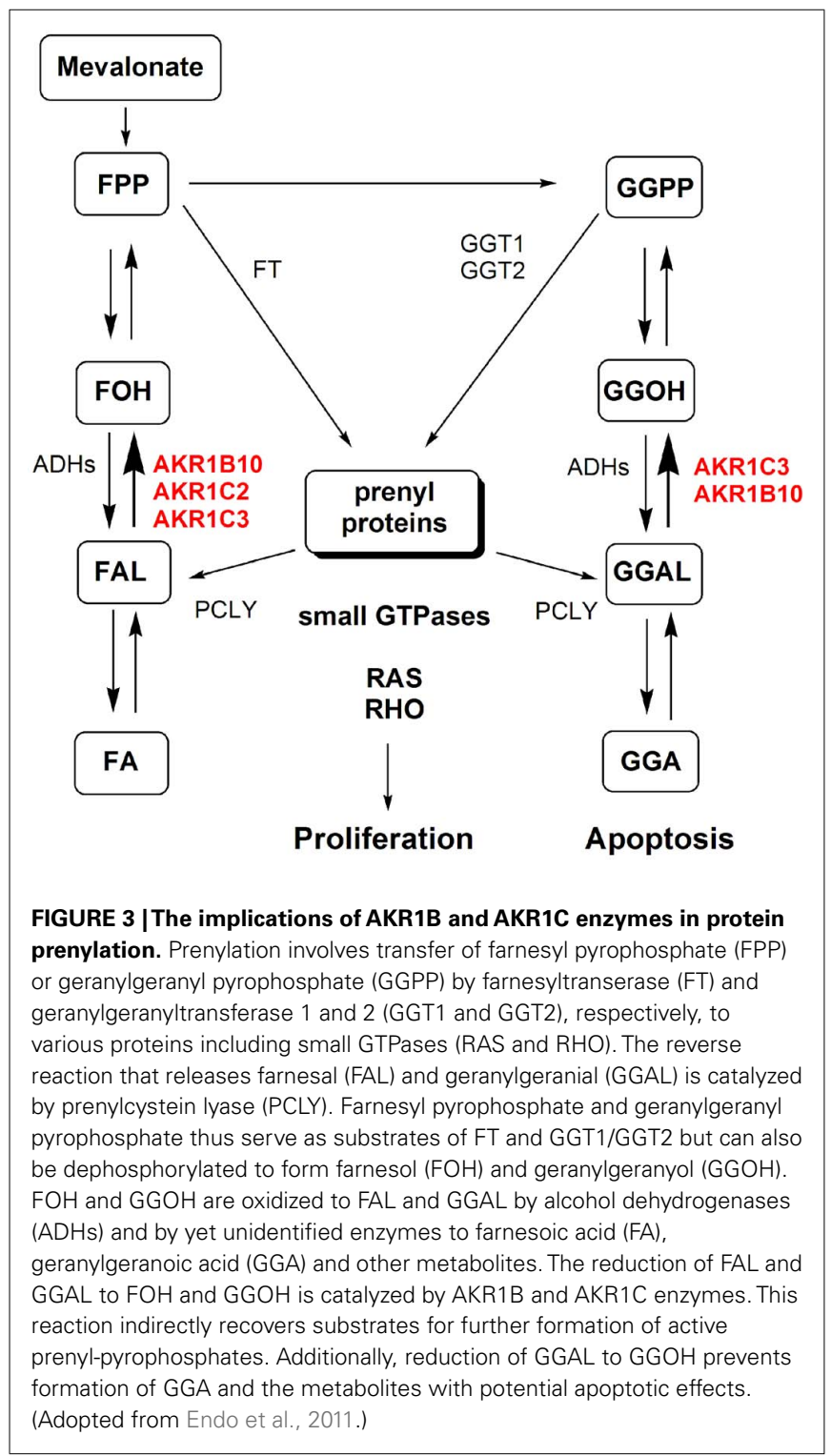

include small GTPases: RAS and RHO proteins (Novelli and D'Apice, 2012). These prenylated proteins are integral components of signaling networks that regulate cell proliferation, differentiation, migration, and apoptosis (Berndt et al., 2011; Novelli and D'Apice, 2012). Prenylation involves transfer of farnesyl pyrophosphate (15-carbon chain) or geranylgeranyl pyrophospate (20-carbon chain), which both originate from the mevalonate pathway, to cysteine residue of these proteins and is catalyzed by farnesyltranserase (FT) and geranylgeranyltransferase 1 (GGT1) and GGT2, respectively. Prenylcystein lyase (PCLY) catalyzes the reverse reaction that releases FAL and GGAL from prenylated proteins (Digits et al., 2002). Farnesyl pyrophosphate and geranylgeranyl pyrophosphate thus serve as substrates for FT and GGT1/GGT2 but can as well be dephosphorylated to form farnesol $(\mathrm{FOH})$ and geranylgeranyol (GGOH; reviewed by Matsunaga et al., 2012). FOH and GGOH are oxidized to FAL and GGAL by ADHs and further to farnesoic acid (FA), geranylgeranoic acid (GGA), and other metabolites. The reduction of FAL and GGAL to FOH and GGOH, catalyzed by AKR1B enzymes, thus recovers substrates for further phosphorylation to corresponding pyrophosphates. Additionally, AKR1B10 with the highest catalytic efficiency for reduction of GGAL prevents formation of GGA and other metabolites with diverse biological effect, including induction of apoptosis (reviewed in Matsunaga et al., 2012). In this manner AKR1B10 prevents formation of pro-apoptotic metabolites and promotes prenylation and activation of small GTPases and further intracellular signaling (reviewed in Matsunaga et al., 2012). Inhibitors of FT (FTI) and GGT1 (GT1I) have already been developed as potential anticancer agents and several clinical trials have been reported for FTI, while the first GGT1I recently entered the clinic (Berndt et al., 2011). FTIs have shown a very limited application in cancer patients, therefore there is a need for novel drug targets within the prenylation pathway, with a potential for AKR1B10. As a secretory protein (Luo et al., 2011), AKR1B10 also represents a potential novel biomarker not only of liver and lung cancer, but also of uterine cancers, and especially of cervical cancer.

\section{THE ENZYMES OF THE AKR1C SUBFAMILY}

The AKR1C subfamily includes four human enzymes AKR1C1, AKR1C2, AKR1C3, and AKR1C4, which share high percentages of amino-acid identities (84-98\%). AKR1C1 and AKR1C2, for instance, differ in only seven amino-acid residues. These enzymes function in vivo as 3-keto-, 17-keto-, and 20-ketosteroid reductases to varying extents (Table 4), and they thus regulate the activity of androgens, estrogens, and progesterone, and the occupancy and transactivation of the corresponding receptors (Penning et al., 2000; Steckelbroeck et al., 2004). The AKR1C isozymes are also involved in PG metabolism (Table 4). AKR1C3 catalyzes the formation of PGF $2 \alpha$ from PGH2, and $9 \alpha, 11 \beta$-PGF2 from PGD2, and in this manner prevents the formation of the pro-apoptotic 15-deoxy-PGJ2 (Byrns et al., 2010). AKR1C1 and AKR1C2, on the other hand, convert PGE2 to PGF2 $\alpha$ and also have lower 11 -ketoreductase activities to reduce PGD2 to $9 \alpha, 11 \beta$-PHF $2 \alpha$ (Nishizawa et al., 2000; Dozier et al., 2008). The AKR1C enzymes reduce isoprenyl aldehydes and may be implicated in prenylation of cellular proteins (Table 4; Matsunaga et al., 2012). Recently it 
Table 4 | Kinetic parameters of the AKR1C1, AKR1C2, and AKR1C3 enzymes

\begin{tabular}{|c|c|c|c|c|c|c|c|c|c|c|}
\hline \multirow[t]{2}{*}{ Substrate } & \multicolumn{3}{|c|}{ AKR1C1 } & \multicolumn{3}{|c|}{ AKR1C2 } & \multicolumn{3}{|c|}{ AKR1C3 } & \multirow[t]{2}{*}{ References } \\
\hline & $K_{\mathbf{M}}(\mu \mathrm{M})$ & $\begin{array}{l}k_{\text {cat }} \\
\left(\min ^{-1}\right)\end{array}$ & $\begin{array}{l}k_{\text {cat }} / K_{M} \\
\left(\mathrm{mM}^{-1}\right. \\
\left.\min ^{-1}\right)\end{array}$ & $K_{\mathbf{M}}(\mu \mathrm{M})$ & $\begin{array}{l}k_{\text {cat }} \\
\left(\min ^{-1}\right)\end{array}$ & $\begin{array}{l}k_{\mathrm{cat}} / K_{\mathrm{M}} \\
\left(\mathrm{mM}^{-1}\right. \\
\left.\min ^{-1}\right)\end{array}$ & $K_{\mathbf{M}}(\mu \mathrm{M})$ & $\begin{array}{l}k_{\text {cat }} \\
\left(\min ^{-1}\right)\end{array}$ & $\begin{array}{l}k_{\mathrm{cat}} / K_{\mathrm{M}} \\
\left(\mathrm{mM}^{-1}\right. \\
\left.\min ^{-1}\right)\end{array}$ & \\
\hline Progesterone & 5.7 & 0.93 & 210 & ND & ND & ND & 2.8 & 1.04 & 370 & Sharma et al. (2006) \\
\hline Progesterone & 1.9 & 0.57 & 300 & 7.7 & 0.21 & 30 & 5.6 & 0.168 & 30 & Beranič et al. $(2011,2012)$ \\
\hline Estrone & ND & ND & ND & ND & ND & ND & 9 & 0.068 & 7.6 & Byrns et al. (2010) \\
\hline $5 \alpha-\mathrm{DHP}$ & 1.1 & 2.6 & 2,400 & 0.6 & 0.48 & 800 & ND & 0.06 & ND & Higaki et al. (2003) \\
\hline $3 \alpha, 5 \alpha-\mathrm{THP}$ & 2.0 & 4.4 & 2,200 & 3.1 & 0.26 & 80 & ND & ND & ND & Higaki et al. (2003) \\
\hline $20 \alpha, 5 \alpha-\mathrm{THP}$ & 0.7 & 0.6 & 860 & 0.5 & 0.48 & 960 & 2.1 & 0.52 & 250 & Higaki et al. (2003) \\
\hline PGD2 & ND & ND & ND & ND & ND & ND & 1.1 & 1.4 & 1,270 & Matsuura et al. (1998) \\
\hline PGD2 & 140 & 0.015 & 0.11 & 120 & ND & ND & 3 & 3.7 & 1,200 & Nishizawa et al. (2000) \\
\hline PGE2 & 1,400 & 0.48 & 0.34 & 98 & 0.082 & 0.83 & LA & LA & LA & Nishizawa et al. (2000) \\
\hline All-trans-retinal & LA & LA & LA & NA & NA & NA & 1.4 & 0.60 & 430 & Ruiz et al. (2011b) \\
\hline 9-cis-retinal & 0.48 & 0.18 & 370 & NA & NA & NA & 0.4 & 13 & 32500 & Ruiz et al. (2011b) \\
\hline Farnesal & 3.1 & 1.7 & 550 & 1.1 & 1.8 & 1,600 & 2.6 & 2.7 & 1,100 & Endo et al. (2011) \\
\hline Geranylgeranial & ND & ND & ND & ND & ND & ND & 0.3 & 3.6 & 12,000 & Endo et al. (2011) \\
\hline
\end{tabular}

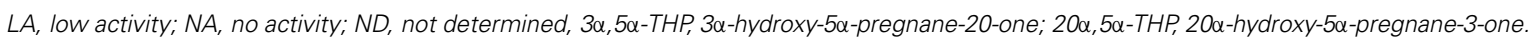

has been reported that AKR1C3 also catalyzes reduction of retinaldehydes, especially 9-cis-retinaldehyde with surprisingly higher catalytic efficiency as compared to other substrates (Ruiz et al., 2011b). The AKR1C enzymes act as phase I metabolism enzymes, and they are responsible for metabolism and clearance of different xenobiotics, and are thus implicated in resistance to treatments with different drugs (Huang et al., 2010; Le Calve et al., 2010). The AKR1C enzymes also convert $5 \alpha$-dihydroprogesterone ( $5 \alpha$ DHP; Table 4) to the $3 \alpha$-hydroxy-metabolite, the most potent positive allosteric modulator of the $\gamma$-aminobutyric acid type A $\left(\mathrm{GABA}_{\mathrm{A}}\right)$ receptor, as well as to the less potent $20 \alpha$-hydroxymetabolite. In this manner AKR1C enzymes are implicated in the production of active neurosteroids. As $5 \alpha$-pregnanes stimulate proliferation of breast cancer cells, the AKR1C enzymes are also involved in the production of pro-proliferative metabolites (Wiebe, 2006). AKR1C2 preferentially catalyzes the formation of $3 \alpha$-hydroxy-5 $\alpha$-pregnane-20-one, while AKR1C1 and AKR1C3 mainly form 20 $\alpha$-hydroxy-metabolites (Usami et al., 2002). The AKR1C enzymes, except AKR1C4 which is liver specific, are expressed in different normal and diseased tissues and have thus been related to several diseases, such as lung, breast, prostate, endometrial cancer, myeloid leukemia, and others. Structurally diverse inhibitors have been reported and in spite the high aminoacid identity also selective inhibitors of individual isoforms have been reported (reviewed in Brožic et al., 2011; Byrns et al., 2011).

\section{THE AKR1C ENZYMES AND THE UTERUS}

Expression of the AKR1C genes has been reported in human uterus (Nishizawa et al., 2000; Penning et al., 2000; Table 5). In endometrium, semiquantitative RT-PCR analysis revealed significantly higher mRNA levels of AKR1C1 in the secretory phase (Nakajima et al., 2003). As the concentrations of PGF2 $\alpha$ increase during the secretory phase and PGF2 $\alpha$ can activate the
AKR1C1 promoter (Nishizawa et al., 2000), this leads to increased expression of AKR1C1. Also mRNA levels of AKR1C3 are the highest in the early secretory phase (Catalano et al., 2011), while expression of $A K R 1 C 2$ throughout the menstrual phases has not yet been examined. To date, expression at the protein/cellular levels has been studied only for AKR1C3 (Pelletier et al., 1999). In paraffin sections of normal endometrium no significant differences in the presence of AKR1C3 were reported during the menstrual phases (Ito et al., 2006). However, these authors provided no information on the specificities of their antibodies. As AKR1C1, AKR1C2, and AKR1C3 have more than 87\% identical amino acids, the antibodies might well have detected all of the three isoforms; thus these data should be considered with caution.

The AKR1C genes are not expressed only in the endometrium. Expression of $A K R 1 C 1$ and $A K R 1 C 3$ has been detected also in myometrium (Lee et al., 2008; Phillips et al., 2011; Table 5). The authors concluded that the increased $A K R 1 C 1$ expression may

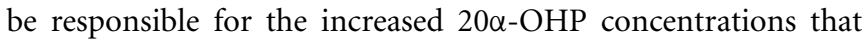
are associated with spontaneous labor, and they suggested that induced labor is not dependent on AKR1C1 (Lee et al., 2008). Expression of the AKR1C genes have been detected also in the human cervix (Andersson et al., 2008; Table 5). In human cervical fibroblasts IL-1 $\beta$ significantly induced $A K R 1 C 1$ and $A K R 1 C 3$, therefore the authors hypothesized that lower uterine infections during pregnancy, with the concomitant production of cytokines, might increase the expression of $A K R 1 C 1$ and $A K R 1 C 3$ and thus accelerate progesterone metabolism to $20 \alpha-\mathrm{OHP}$ in cervical fibroblasts. This would potentially have a major impact on cervical structure, with an increase in the likelihood of a preterm birth (Roberson et al., 2011).

Studies have thus shown that the AKR1C genes AKR1C1 and $A K R 1 C 3$ are expressed in the normal uterus within the endometrium, myometrium, and cervical canal (Table 5). AKR1C1 is the major human 20-ketosteroid reductase, and 
Table 5 | Expression of $A K R 1 C 1, A K R 1 C 2$, and $A K R 1 C 3$ in human uterus

\begin{tabular}{|c|c|c|}
\hline Isoform & Level & Tissue \\
\hline & & Uterus \\
\hline \multirow{3}{*}{$\begin{array}{l}\text { AKR1C1, AKR1C2, } \\
\text { AKR1C3 }\end{array}$} & mRNA & $A K R 1 C 2>A K R 1 C 3>>A K R 1 C 1$ \\
\hline & & $A K R 1 C 3>A K R 1 C 1>>A K R 1 C 2$ \\
\hline & & Endometrium \\
\hline AKR1C1 & mRNA & $\begin{array}{l}\text { Higher levels in secretory phase. } \\
\text { Induced by PGF } 2 \alpha \text {. }\end{array}$ \\
\hline AKR1C3 & & Higher levels in early secretory ph \\
\hline AKR1C2 & & Not evaluated. \\
\hline AKR1C3 & Protein & $\begin{array}{l}\text { Epithelial cells of endometrial glan } \\
\text { No significant difference between }\end{array}$ \\
\hline \multirow[t]{2}{*}{ AKR1C1, AKR1C } & & Not evaluated. \\
\hline & & Myometrium \\
\hline AKR1C1 & mRNA & $\begin{array}{l}\text { Significantly increased in women i } \\
\text { difference in women with induced }\end{array}$ \\
\hline \multirow{3}{*}{\multicolumn{2}{|c|}{$\begin{array}{l}\text { AKRTC3 } \\
\text { AKR1C2 }\end{array}$}} & No difference between pregnant/n \\
\hline & & Not evaluated. \\
\hline & & Cervix \\
\hline \multirow[t]{2}{*}{ AKR1C1, AKR1C2, AKR1C3 } & mRNA & $\begin{array}{l}\text { AKR1C1 > AKR1C2 (7-fold) AKR1C } \\
\text { expression in women before/after } \\
\text { labor. }\end{array}$ \\
\hline & & \\
\hline \multicolumn{3}{|c|}{$\begin{array}{l}\text { it converts progesterone to } 20 \alpha-O H P \text { (Nishizawa et al., 2000; } \\
\text { Lanišnik Rižner et al., 2006). AKR1C3 acts as a 17-ketosteroid } \\
\text { reductase, and activates estrone to estradiol, while it also acts as } \\
\text { a } 20 \text {-ketosteroid reductase, albeit with } 10 \text {-fold lower catalytic eff- } \\
\text { ciency than that seen for AKR1C1 (Penning et al., 2000; Beranič } \\
\text { et al., 2011). Additionally, AKR1C3 can act as PGF2 } \alpha \text { synthase } \\
\text { (Dozier et al., 2008). AKR1C3 detected in endometrial glands of } \\
\text { normal endometrium (Pelletier et al., 1999; Ito et al., 2006) may } \\
\text { thus be related to PGF2 } \alpha \text { formation and progesterone metabolism. } \\
\text { The higher levels of } A K R 1 C 1 \text { mRNA in the secretory endometrium } \\
\text { are probably associated with increased PGF2 } \alpha \text { concentrations, } \\
\text { and the higher levels of AKR1C1 mRNA in myometrium, with } \\
\text { spontaneous labor (Nakajima et al., 2003; Lee et al., 2008). In } \\
\text { late secretory phase endometrium and in myometrium, AKR1C1 } \\
\text { thus contributes to decreased local concentrations of progesterone. } \\
\text { Induction of } A K R 1 C 1 \text { and AKR1C3 by IL-1 } \beta \text { might be related to } \\
\text { preterm labor caused by uterine infection (Roberson et al., 2011). } \\
\text { Finally, although AKR1C2 was reported to be the predominate } \\
\text { AKR1C isoform of the whole uterus (Penning et al., 2000), its } \\
\text { expression and its role in endometrium and myometium have not } \\
\text { yet been studied. }\end{array}$} \\
\hline
\end{tabular}

\section{THE AKR1C ENZYMES IN ENDOMETRIAL AND CERVICAL CANCER}

The expression of the $A K R 1 C$ genes in endometrial cancer has been studied mainly by three groups (Table 6). We detected $A K R 1 C 1, A K R 1 C 2$, and $A K R 1 C 3$ mRNA levels in paired samples of cancerous endometrium and adjacent control endometrium (Lanišnik Rižner et al., 2006; Šmuc and Lanišnik Rižner, 2009). The differences in expression were not statistically significant, but our pair-wise comparison suggested that in some patients, increased levels of AKR1C1 and/or AKR1C3 might be associated with pathophysiology of endometrial cancer. At the cellular level, Ito et al. (2006) reported increased AKR1C3 immunoreactivity in endometrial hyperplasia and endometrial carcinoma. Although this was without showing any experimental data for the sections or clinical data of the patients, and without sufficient information on the antibodies, the authors suggested that AKR1C3 is one of the key enzymes in the local regulation of estrogen concentrations in endometrial malignancies (Ito et al., 2006). Our group used a wellcharacterized and specific monoclonal antibody against AKR1C3 (Lin et al., 2004), which stained all 10 paraffin sections of cancerous endometrium (Šmuc and Lanišnik Rižner, 2009). Using the same antibody, Zakhaorov et al. (2010) showed weaker AKR1C3 staining in hyperplastic endometrium and cancerous endometrium, versus the normal proliferative endometrium. However, such comparisons should also be interpreted with caution, due to differences between the groups according to menopausal status, and due to the small number of patients. In contrast to women with normal endometrium (pre-menopausal; mean age, 31.5 years) and patients with endometrial hyperplasia (2 out of 8 postmenopausal; mean age, 47.8), the majority of endometrial cancer patients were post-menopausal ( 8 out of 12 , mean age 58.4), as expected, and there was a significant age difference between the control and the endometrial cancer groups.

Among the AKR1C genes, expression of $A K R 1 C 1, A K R 1 C 2$, and $A K R 1 C 3$ was detected in endometrial cancer and adjacent control endometrium, and increased mRNA levels of AKR1C1 and $A K R 1 C 3$ were seen in some patients (Lanišnik Rižner et al., 2006; Šmuc and Lanišnik Rižner, 2009). However, on average, no significant differences were observed at the mRNA level, and immunohistochemical analysis revealed lower AKR1C3 levels in the hyperplastic and cancer endometrium (Zakhaorov et al., 2010). 
Table 6 | Expression of $A K R 1 C 1, A K R 1 C 2$, and $A K R 1 C 3$ in uterine diseases

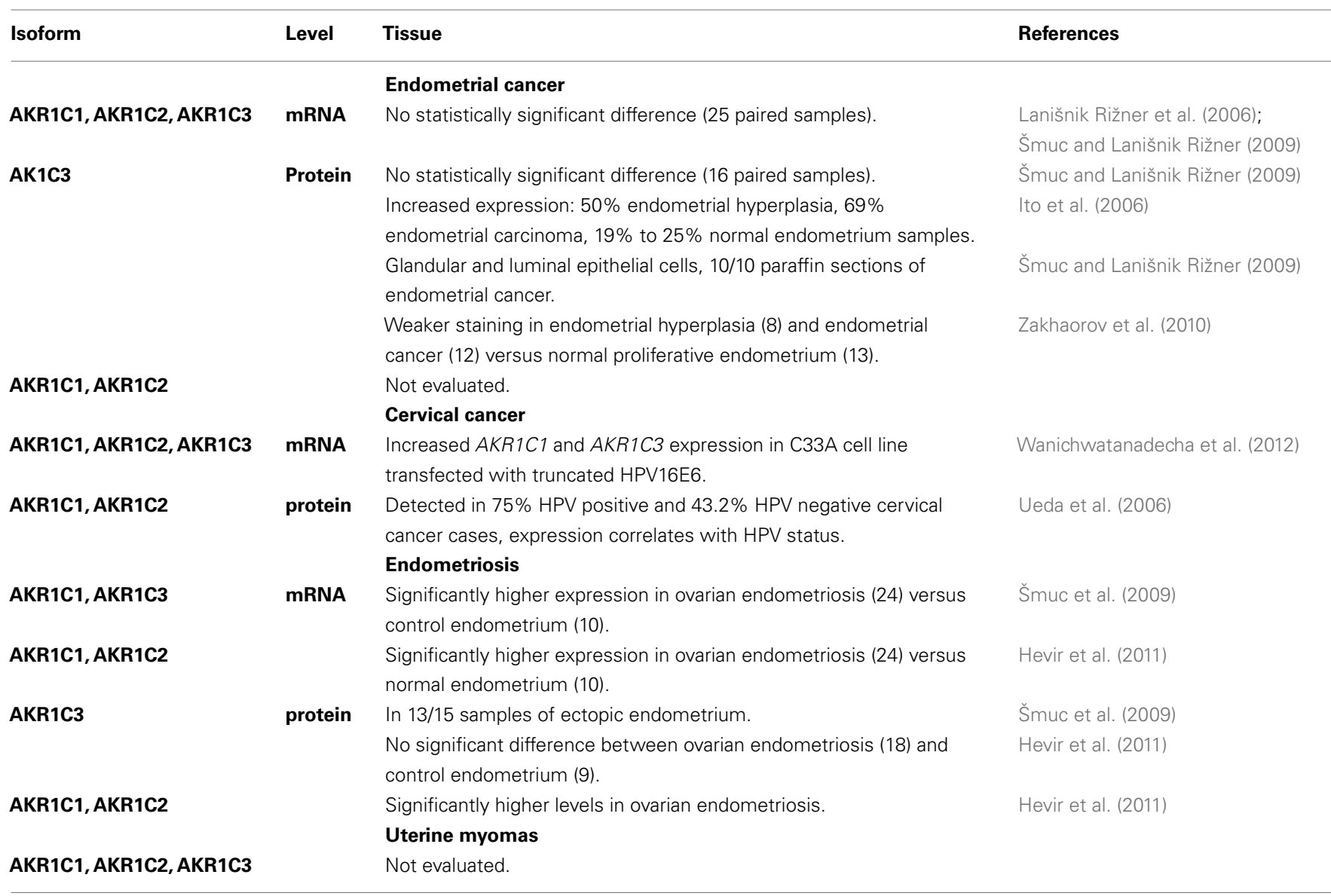

It is clear here that AKR1C3 expression in endometrial cancer needs to be further studied at the protein level on a larger number of endometrial cancer samples with the specific antibodies that are available. The menopausal status of the patients should also be taken into consideration, and therefore comparisons between post-menopausal cancer endometrium and control endometrium of the same patient should be used. Additionally, the expression of AKR1C1 and AKR1C2 remain to be studied further.

The AKR1C1 and AKR1C2 enzymes have also been detected in cervical cancer patients with significant correlation to HPV infection and poorer survival rate (Ueda et al., 2006). Interestingly, the up-regulation of $A K R 1 C 1$ and $A K R 1 C 3$ genes have been reported in cervical cancer $\mathrm{C} 33 \mathrm{~A}$ cell line stably transfected with truncated HPV16 oncoprotein E6 (Wanichwatanadecha et al., 2012). The authors suggested that the increased levels of AKR1C1 and AKR1C3 may be involved in drug resistance, a major problem in treatment of cervical cancer.

\section{THE AKR1C ENZYMES IN ENDOMETRIOSIS}

Our group was the first to show expression of the $A K R 1 C$ genes in endometriosis (Table 6). Significantly higher mRNA levels of $A K R 1 C 1, A K R 1 C 2$, and $A K R 1 C 3$ were seen in ovarian endometriosis versus control endometrium of myoma patients and versus normal endometrium of healthy women (Šmuc et al., 2009; Hevir et al., 2011). At the protein level, AKR1C3 was detected in ectopic endometrium (Šmuc et al., 2009) and immunohistochemical staining showed no significant differences in AKR1C3 scores, but a significant increase in AKR1C2 total scores (Hevir et al., 2011). Although the comparisons to normal endometrium still need to be done, our data suggest that the AKR1C enzymes, and especially AKR1C1 and AKR1C2, may be associated with the development of ovarian endometriosis. Increased levels of AKR1C1 and $\mathrm{AKR} 1 \mathrm{C} 2$ in endometriotic tissue might also contribute to enhanced metabolism of the protective progesterone, and to the formation of the pro-proliferative $5 \alpha$-pregnanes (Wiebe, 2006; Beranič and Lanišnik Rižner, unpublished data). To the best of our knowledge, there have been no reports on the expression of the AKR1C enzymes in uterine myomas.

THE POTENTIAL ROLE OF THE AKR1C ENZYMES IN UTERINE DISEASES AKR1C3 and AKR1C1 are involved in estradiol formation and progesterone inactivation, respectively (Penning et al., 2000); therefore, their increased levels in diseased endometrium might lead to enhanced proliferation stimulated by estrogens. It has long been known that estrogen actions that remain unopposed by the protective actions of progesterone are related to the development of uterine diseases, endometrial hyperplasia, endometrial cancer, and endometriosis (Inoue, 2001). The increased levels of AKR1C3 that have been seen in some endometrial cancer patients (Lanišnik Rižner et al., 2006; Šmuc et al., 2009) might increase 
local concentrations of estradiol and might decrease the concentrations of progesterone, by its 17-ketosteroid and 20-ketosteroid reductase activities, respectively. Increased levels of AKR1C1, the major human 20-ketosteroid reductase, which is also seen in some endometrial cancer patients, might result in enhanced metabolism of progesterone. Also, in ovarian endometriosis, increased levels of AKR1C3 and AKR1C1 might have similar effects on local estradiol and progesterone concentrations. As the growth of uterine myomas is hormone dependent, AKR1C1 and AKR1C3 might also be associated with the development of these benign tumors.

The AKR1C enzymes are involved in the metabolism of $5 \alpha$ DHP. In breast cancer $5 \alpha$-pregnanes have been shown to stimulate cell proliferation and detachment (Wiebe, 2006), and also our unpublished studies have confirmed their stimulatory effects on the Z12 endometriotic cell line (Beranič and Lanišnik Rižner, unpublished data). Due to increased levels of $5 \alpha$-reductase type 1 in endometriosis (Hevir et al., 2011), which catalyzes the formation of $5 \alpha$-DHP, the AKR1C enzymes might be responsible for enhanced formation of its pro-proliferative $3 \alpha / \beta$ - and $20 \alpha$ hydroxy-metabolites. Interestingly, in vitro the catalytic activity of the AKR1C enzymes can be blocked by progestins (Beranič et al., 2011, 2012), which are used for the treatment of endometriosis, such as medroxyprogesterone acetate and dydrogesterone. Increased levels of AKR1C1-AKR1C3 and 5 $\alpha$-reductase type 1 in endometriosis might thus lead to enhanced metabolism of progesterone toward the formation of $5 \alpha$-pregnanes (Hevir et al., 2011). Also, in some endometrial cancer patients, and especially those who are pre-menopausal, and possibly also in patients with myoma, AKR1C1-AKR1C3 may have a similar role.

The AKR1C enzymes are also implicated in PG biosynthesis, forming PGF $2 \alpha$ and $9 \alpha, 11 \beta$-PGF2 $\alpha$ (Nishizawa et al., 2000; Dozier et al., 2008). These PGs have similar affinities for the FP receptor (Dozier et al., 2008), and both activate this receptor, which exerts diverse responses via the MAPK signaling cascades, including inflammation and proliferation (Figure 1). These actions are mediated through the activation of NF- $\kappa \mathrm{B}$ and the inactivation of PPAR $\gamma$. By converting PGH2 to PGF $2 \alpha$ and PGD2 to $9 \alpha, 11 \beta$ PGF2, the AKR1C enzymes prevent the formation of the antiproliferative and anti-inflammatory 15d-PGJ2. This PG covalently modifies, and thus activates, PPAR $\gamma$, while it inactivates NF- $\kappa$ B (Byrns and Penning, 2007). These mechanisms might be used mainly by AKR1C3 but also other AKR1C enzymes in the pathogenesis of cancer endometrium and endometriosis, and possibly also in other uterine diseases.

Similarly as AKR1B enzymes, also AKR1C1 and especially AKR1C3, act as isoprenyl aldehyde reductases (Endo et al., 2011) and retinal reductases (Ruiz et al., 2011b) with higher catalytic efficiencies for GGAL and 9-cis-retinal, respectively. As described for AKR1B10 also AKR1C1 and AKR1C3 may be involved in protein

\section{REFERENCES}

Abu, J., Batuwangala, M., Herbert, K., and Symonds, P. (2005). Retinoic acid and retinoid receptors: potential chemopreventive and therapeutic role in cervical cancer. Lancet Oncol. 6, 712-720.
Alexiou, P., Pegklidou, K., Chatzopoulou, M., Nicolaou, I., and Demopoulos, V. J. (2009). Aldose reductase enzyme and its implication to major health problems of the 21st century. Curr. Med. Chem. 16, 734-752.

prenylation (Figure 3) with potential stimulation of proliferation and may also deprive RAR and RXR from their ligand, retinoic acid, which leads to loss of cell differentiation (Figure 2). This suggests that inhibitors of AKR1C1 and AKR1C3 would block formation of these prenylated proteins and pro-differentiating retinoic acid. Last but not least, AKR1C enzymes may also be responsible for drug resistance, a frequent and serious problem in treatment of cervical cancer.

\section{CONCLUSION AND PERSPECTIVES}

In uterine diseases gene expression and the role of the AKR1C enzymes have been most studied among the enzymes of the AKR1B and AKR1C subfamilies. There are several reports on the expression of AKR1Cs in endometrial cancer, cervical cancer, and endometriosis, while there are only two studies on the expression of $A K R 1 B$ in endometrial and cervical cancers. Currently, there are no reports showing the presence of the AKR1B enzymes in uterine myomas and endometriosis, nor of AKR1C in uterine myomas.

$\mathrm{AKR} 1 \mathrm{~B}$ and AKR1C enzymes are involved in processes that are implicated in the pathophysiology of uterine diseases; therefore, it is clear that these enzymes need to be further investigated. First, we need information on the expression of AKR1Bs and AKR1Cs in all parts of the human uterus at the mRNA, protein, and cellular levels, and in diseased versus normal tissues. Secondly, the appropriate model cell lines together with overexpression of individual genes and siRNA approach should be used to delineate the enzymatic activities and the involvement of the salient enzymes in the proposed pathways. As specific inhibitors of these AKR1B and AKR1C enzymes have already been developed these can then be tested in these appropriate cell models.

If further studies reveal the involvement of these AKR1B and AKR1C enzymes in the pathophysiology of uterine diseases, these enzymes would represent potential drug targets. The inhibitors would block the biosynthesis of the proliferative PGF2 $\alpha$ (AKR1B1, AKR1C3) and estradiol (AKR1C3), formation of prenylated proteins, which may stimulate proliferation (AKR1B10, AKR1C3), the biosynthesis of $9 \alpha, 11 \beta$-PGF2 (AKR1C3), which deprives proapoptotic PPAR $\gamma$ of its ligand, and the biosynthesis of retinol (AKR1B10), which decreases the concentrations of retinoic acid and prevents cell differentiation. These inhibitors might block the proliferative effects and the pathological inflammation in the endometrium, myometrium and cervix, and might thus be efficacious as therapies for women with uterine diseases. Furthermore, there is support for these enzymes, and especially for the secretory AKR1B10, to be used as novel diagnostic markers.

\section{ACKNOWLEDGMENTS}

This study was supported by a J3-4135 grant to T.L.R. from the Slovenian Research Agency. The author thanks Dr. Chris Berrie for critical reading of the manuscript.

Amant, F., Moerman, P., Neven, P., Timmerman, D., Van Limbergen, E., and Vergote, I. (2005). Endometrial cancer. Lancet 366, 491-505.

Andersson, S., Minjarez, D., Yost, N. P., and Word, R. A. (2008). Estrogen and progesterone metabolism in the cervix during pregnancy and parturition. J. Clin. Endocrinol. Metab. 93, 2366-2374.

Banu, S. K., Starzinski-Powitz, A., Speights, V. O., Burghardt, R. C., and Arosh, J. A. (2009). Induction of peritoneal endometriosis in nude 
mice with use of human immortalized endometriosis epithelial and stromal cells: a potential experimental tool to study molecular pathogenesis of endometriosis in humans. Fertil. Steril. 91, 2199-2209.

Barski, O. A., Tipparaju, S. M., and Bhatnagar, A. (2008). The aldoketo reductase superfamily and its role in drug metabolism and detoxification. Drug Metab. Rev. 40, 553-624.

Beranič, N., Brožic, P., Brus, B., Sosic, I., Gobec, S., and Lanišnik Rižner, T. (2012). Expression of human aldoketo reductase $1 \mathrm{C} 2$ in cell lines of peritoneal endometriosis: potential implications in metabolism of progesterone and dydrogesterone and inhibition by progestins. J. Steroid. Biochem. Mol. Biol. 130, 16-25.

Beranič, N., Gobec, S., and Lanišnik Rižner, T. (2011). Progestins as inhibitors of the human 20ketosteroid reductases, $\mathrm{AKR} 1 \mathrm{C} 1$ and AKR1C3. Chem. Biol. Interact. 191, 227-233.

Berkley, K. J., Rapkin, A. J., and Papka, R. E. (2005). The pains of endometriosis. Science 308, 1587-1589.

Berndt, N., Hamilton, A. D., and Sebti, S. M. (2011). Targeting protein prenylation for cancer therapy. Nat. Rev. Cancer 11, 775-791.

Bresson, E., Boucher-Kovalik, S., Chapdelaine, P., Madore, E., Harvey, N., Laberge, P. Y. L., Leboeuf, M., and Fortier, M. A. (2011). The human aldose reductase AKR1B1 qualifies as the primary prostaglandin $\mathrm{F}$ synthase in the endometrium. J. Clin. Endocrinol. Metab. 96, 210-219.

Brožic, P., Turk, S., Lanišnik Rižner, T., and Gobec, S. (2011). Inhibitors of aldo-keto reductases AKR1C1AKR1C4. Curr. Med. Chem. 18, 2554-2565.

Bulun, S. E. (2009). Endometriosis. N. Engl. J. Med. 360, 268-279.

Byrns, M. C., Duan, L., Lee, S. H., Blair, I. A., and Penning, T. M. (2010). Aldo-keto reductase $1 \mathrm{C} 3$ expression in MCF-7 cells reveals roles in steroid hormone and prostaglandin metabolism that may explain its overexpression in breast cancer. J. Steroid Biochem. Mol. Biol. 118, 177-187.

Byrns, M. C., Jin, Y., and Penning, T. M. (2011). Inhibitors of type 5 $17 \alpha$-hydroxysteroid dehydrogenase (AKR1C3): overview and structural insights. J. Steroid Biochem. Mol. Biol. 125, 95-104.

Byrns, M. C., and Penning, T. M. (2007). "Selective inhibitors of AKR1C3 as anti-proliferative agents," in Enyzmology and Molecular Biology of Carbonyl Metabolism, eds H. Weiner,
E. Maser, R. Lindahl, and B. Plapp (West Lafayette: Purdue University Press), 242-251.

Carter, C. A. (2003). Retinoic acid signaling through PI-3-kinase induces differentiation of human endometrial adenocarcinoma cells. Exp. Mol. Pathol. 75, 34-44.

Catalano, R. D., Wilson, M. R., Boddy, S. C., and Jabbour, H. N. (2011). Comprehensive expression analysis of prostanoid enzymes and receptors in the human endometrium across the menstrual cycle. Mol. Hum. Reprod. 17, 182-192.

Chapdelaine, P., Kang, J., BoucherKovalik, S., Caron, N., Tremblay, J. P., and Fortier, M. A. (2006). Decidualization and maintenance of a functional prostaglandin system in human endometrial cell lines following transformation with SV40 large $\mathrm{T}$ antigen. Mol. Hum. Reprod. 12, 309-319.

Cheng, Y. H., Utsunomiya, H., Pavone, M. E., Yin, P., and Bulun, S. E. (2011). Retinoic acid inhibits endometrial cancer growth via multiple genomic mechanisms. J. Mol. Endocrinol. 46, 139-153.

Chung, S. H., Franceschi, S., and Lambert, P. H. (2010). Estrogen and Era: culprits in cervical cancer? Trends Endocrinol. Metab. 21, 504-511.

Digits, J. A., Pyun, H. J., Coates, R. M., and Casey, P. J. (2002). Stereospecificity and kinetic mechanism of human prenylcysteine lyase, an unusal thioether oxidase. J. Biol. Chem. 277, 41086-41093.

Dozier, B. L., Watanabe, K., and Duffy, D. M. (2008). Two pathways for prostaglandin F2 $\alpha$ synthesis by the primate periovulatory follicle. Reproduction 136, 53-63.

Endo, S., Matsunaga, T., Ohta, C., Soda, M., Kanamori, A., Kitade, Y., Ohno, S., Tajima, K., El-Kabbani, O., and Hara, A. (2011). Roles of rat and human aldo-keto reductases in metabolism of farnesol and geranylgeraniol. Chem. Biol. Interact. 191, 261-268.

Endo, S., Matsunaga, T., Soda, M., Tajima, K., Zhao, H. T., El-Kabbani, O., and Hara, A. (2010). Selective inhibition of the tumor marker AKR1B10 by antiinflammatory Nphenylanthranilic acids and glycyrrhetic acid. Biol. Pharm. Bull. 33 , 886-890.

Faridi, R., Zahra, A., Khan, K., and Idrees, M. (2011). Oncogenic potential of human papillomavirus (HPV) and its relation with cerical cancer. Virol. J. 8, 269.

Ferlay, J., Shin, H. R., Bray, F., Forman, D., Mathers. C., and Parkin,
D. M. (2008). GLOBOCAN 2008 v1.2, Cancer Incidence and Mortality Worldwide: IARC CancerBase No. 10, Lyon, France: International Agency for Research on Cancer; 2010. Available at: http://globocan.iarc.fr, accessed on 25/10/2011

Fukumoto, S., Yamauchi, N., Moriguchi, H., Hippo, Y., Watanabe, A., Shibahara, J., Taniguchi, H., Ishikawa, S., Ito, H., Yamamoto, S., Iwanari, H., Hironaka, M., Ishikawa, Y., Niki, T. Sohara, Y., Kodama, T., Nishimura, M., Fukayama, M., Dosaka-Akita H., and Aburatani, H. (2005). Overexpression of the aldo-keto reductase family protein AKR1B10 is highly correlated with smokers' nonsmall cell lung carcinomas. Clin. Cancer Res. 11, 1776-1785.

Giudice, L. C., and Kao, L. C. (2004). Endometriosis. Lancet 364 1789-1799.

Goss, P. E., Shangle, Q., Hu, H., Gediya, L. K., Purushottamachar, P., Godbole, A. M., and Njar, V. C. O. (2011). Anti-tumor effects of a novel retinoic acid metabolism blocking agent VN/14-1 in the N-methyl-Nnitrosourea-induced rat mammary carcinoma model and its effects on the uterus. Breast Cancer Res. Treat. (in press).

Herfs, M., Herman, L., Hubert, P., Minner, F., Arafa, M., Roncarati, P. Henroitin, Y., Boniver, J., and Delvenne, P. (2009). High expression of PGE2 enzymatic pathway in cervical (pre)neoplastic lesions and functional consequences for antigenpresenting cells. Cancer Immunol. Immunother. 58, 603-614.

Hevir, N., Vouk, K., Šinkovec, J., RibicPucelj, M., and Lanišnik Rižner, T. (2011). Aldo-keto reductases AKR1C1, AKR1C2 and AKR1C3 may enhance progesterone metabolism in ovarian endometriosis. Chem. Biol. Interact. 191, 217-226.

Higaki, Y., Usami, N., Shintani, S., Ishikura, S., El-Kabbani, O., and Hara, A. (2003). Selective and potent inhibitors of human $20 \alpha$ hydroxysteroid dehydrogenase (AKR1C1) that metabolizes neurosteroids derived from progesterone. Chem. Biol. Interact. 143/144, 503-513.

Hompes, P. G., and Mijatovic, V. (2007). Endometrisis: the way forward. Gynecol. Endocrinol. 23, 5-12.

Huang, K. H., Chiou, S. H., Chow, K. C., Lin, T. Y., Chang, H. W., Chiang, I. P., and Lee, M. C. (2010). Overexpression of aldo-keto reductase $1 \mathrm{C} 2$ is associated with disease progression in patients with prostatic cancer. Histopathology 57, 384-394.
Inoue, M. (2001). Current molecular aspects of the carcinogenesis of the uterine endometrium. Int. J. Gynecol. Cancer 11, 339-348.

Ito, K., Utsunomiya, H., Suzuki, T., Saitou, S., Akahira, J., Okamura, K., Yaegashi, N., and Sasano, H. (2006). 17beta-hydroxysteroid dehydrogenases in human endometrium and its disorders. Mol. Cell. Endocrinol. 248, 136-140

Jabbour, H. N., Sales, K. J., Milling Smith, O. P., Battersby, S., and Boddy S. C. (2006). Prostaglandin receptors are mediators of vascular function in endometrial pathologies. Mol. Cell. Endocrinol. 252, 191-200.

Kabututu, Z., Manin, M., Pointud, J. C., Maruyama, T., Nagata, N., Lambert, S., Lefrancois-Martinez, A. M., Martinez, A., and Urade, Y. (2009). Prostaglandin F2 $\alpha$ synthase activities of aldo-keto reductase $1 \mathrm{~B} 1,1 \mathrm{~B} 3$ and 1B7. J. Biochem. 145, 161-168.

Lanišnik Rižner, T., Šmuc, T., Rupreht, R., Šinkovec, J., and Penning, T. M. (2006). AKR1C1 and AKR1C3 may determine progesterone and estrogen ratios in endometrial cancer. Mol. Cell. Endocrinol. 248, 126-135.

Le Calve, B., Rynkowski, M., Le Mercier, M., Bruyere, C., Lonez, C., Gras, T., Haibe-Kains, B., Bontempi, G., Decaestecker, C., Ruysschaert, J. M., Kiss, R., and Lefranc, F. (2010). Long-term in-vitro treatment of human glioblastoma cells with temozolomide increases resistance in vivo through up-regulation of GLUT transporter and aldo-keto reductase enzyme AKR1C expression. Neoplasia 12, 727-739.

Lee, R. H., Stanczyk, F. Z., Stolz, A., Ji, Q., Yang, G., and Goodwin, T. M. (2008). AKR1C1 and SRD5A1 messenger RNA expression at term in the human myometrium and chorioamniotic membranes. Am. J. Perinatol. $25,577-582$.

Lin, H. K., Steckelbroeck, S., Fung, K. M., Jones, A. M., and Penning, T. M. (2004). Characterization of a monoclaonal antibody for human aldoketo reductase AKR1C3 (type $23 \alpha$ hydroxysteroid dehydrogenase/type $517 \alpha$-hydroxysteroid dehydrogenase); immunohistochemical detection in breast and prostate. Steroids 69, 795-801.

Liu, J., Wen, G., and Cao, D. (2009). Aldo-keto reductase family $1 \mathrm{mem}$ ber B1 inhibitors: old drugs with new perspectives. Recent Pat. Anticancer Drug Discov. 4, 256-253.

Liu, Z., Yan, R., Al-saman, A., Shen, Y., Bu, Y., Ma, J., Luo, D. X., Huang, C., Jiang, Y., Wilber, A., Mo, Y. Y., Huang, M. C., Zhao, Y., and Cao, D. (2011). 
Epidermal growth factor induces tumor marker AKR1B10 expression through activator protein-1 signaling in hepatocelluar carcinoma cells. Biochem. J. (in press).

Lousse, J. C., Defrere, S., Collete, S., Van Langendonckt, A., and Donnez, J. (2010). Expression of eicosanoid biosynthetic and catabolic enzymes in peritoneal endometriosis. Hum Reprod. 25, 734-741.

Luo, D., Huang, M. C., Ma, J., Gao, Z., Liao, D. F., and Cao, D. (2011). Aldo-keto reductase family 1 , member B10 is secreted through a lysosome-mediated non-classical pathway. Biochem. J. 438, 71-80.

Matsunaga, T., Wada, Y., Endo, S., Soda, M., El-Kabbani, O., Hara, A. (2012) Aldo-keto reductase $1 \mathrm{~B} 10$ and its role in proliferation capacity of drug-resistant cancers. Front. Pharmacol. doi:10.3389/fphar.2012.00005. (in press).

Matsuura, K., Shiraishi, H., Hara, A., Sato, K., Deyashiki, Y., Ninomiya, M., and Sakai, S. (1998). Identification of a principal mRNA species for human 3alpha-hydroxysteroid dehydrogenase isoform (AKR1C3) that exhibits high prostaglandin D2 11-ketoreductase activity. J. Biochem. 124, 940-946.

Maybin, J. A., Critchley, H. O. D., and Jabbour, H. N. (2011). Inflammatroy pathways in endometrial disorders. Mol. Cell. Endocrinol. 335, 42-51.

Miller, C. E. (2008). Unmet therapeutic need for uterine myomas. J. Minim. Invasive Gynecol. 16, 11-21.

Myga-Nowak, M., Pacholska-Bogalska, J., Kwasniewski, W., Kwasniewska, A., and Gozdzicka-Jozefiak, A. (2011). Proliferation of cells and expression of RARs, RXRs and HPV viral E6 and E7 proteins in cervical cancer cell lines after treatment with ATRA. Ann. Agric. Environ. Med. 18, 145-150.

Nagata, N., Kusakari, Y., Fukunishi, Y., Inoue, T., and Urade, Y. (2011). Catalytic mechanism of the primary human prostaglandin F2 $\alpha$ synthase, aldo-keto reductase 1B1prostaglandin $\mathrm{D} 2$ synthase activity in the absence of $\operatorname{NADP}(\mathrm{H})$. FEBS J. 278, 1288-1298.

Nakajima, T., Yasuda, K., Nishizawa, M., Okada, H., Yoshimura, T., Ito, S., and Kanzaki, H. (2003). Expression

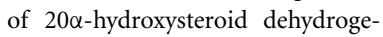
nase mRNA in human endometrioum and decidua. Endocr. J. 50, 105-111.

Nishizawa, M., Nakajima, T., Yasuda, K., Kanzaki, H., Sasaguri, Y., Watanabe, K., and Ito, S. (2000). Close kinship of human 20a-hydroxysteroid dehydrogenase gene with three aldo-keto reductase genes. Genes Cells 5, 111-125.

Nisolle, M., and Donnez, J. (1997). Peritoneal endometriosis, ovarian endometriosis, and adenomyotic nodules of the rectovaginal septum are three different entities. Fertil. Steril. 68, 585-596.

Novelli, G., D’Apice, M. R. (2012). Protein farnesylation and disease. J. Inherit. Metab. Dis. doi:10.1007/s10545-011-9445-y. (in press)

Pavone, M. E., Dyson, M., Reirstad, S., Pearson, E., Ishikawa, H., Cheng, Y. H., and Bulun, S. E. (2011). Endometriosis expresses a molecular pattern consistent with decreased retinol uptake, metabolism and action. Hum. Reprod. 26, 2157-2164.

Pelletier, G., Luu-The, V., Tetu, B., and Labrie, F. (1999). Immunoytochemical localization of type 5 17ß-hydroxyseroid dehydrogeanse in human reproductive tissues. J. Histochem. Cytochem. 47, 731-737.

Penning, T. (2005). AKR1B10: a new diagnostic marker of non-small cell lung carcinoma in smokers. Clin. Cancer Res. 11, 1687-1690.

Penning, T. M., Burczynski, M. E., Jez, J. M., Hung, C. F., Lin, H. K., Ma, H., Moore, M., Palackal, N., and Ratnam, K. (2000). Human $3 \alpha-$ hydroxysteroid dehydrogenase isoforms (AKR1C1-AKR1C4) of the aldo-keto reductase superfamily: functional plasticity and tissue distribution reveals roles in the inactivation and formation of male and female sex hormones. Biochem. J. 351, 67-77.

Penning, T. M., and Drury, J. E. (2007). Human aldo-keto reductases: function, gene regulation, and single nucleotide polymorphism. Arch. Biochem. Biophys. 464, 241-250.

Phillips, R. J., Al-Zamil, H., Hunt, L. P., Fortier, M. A., and Bernal, A. L. (2011). Genes for prostaglandin synthesis, transport and inactivation are differentially expressed in human uterine tissues, and the prostaglandin F synthase AKR1B1 is induced in myometrial cells by inflammatory cytokines. Mol. Hum. Reprod.17, 1-13.

Ramana, K. V. (2011). Aldose reductase: new insights for an old enzyme. Biomol. Concepts 2, 103-114.

Roberson, A. E., Hyatt, K., Kenkel, C., Hanson, K., and Myers, A. A. (2011). Interleukin $1 \mathrm{~b}$ regulates progesterone metabolism in human cervical fibroblasts. Reprod. Sci. (in press).

Rossi, M., Sharkey, A. M., Vigano, P., Fiore, G., Furlong, R., Florio, P., Ambrosini, G., Smith, S. K., and Petragli, F. (2005). Identification of genes regulated by interleukin- $1 \mathrm{~b}$ in human endometrial stromal cells. Reproduction 130, 721-729.

Ruiz, F. X., Moro, A., Gallego, O., Ardevol, A., Rovira, C., Petrash, J. M., Pares, X., and Farres, J. (2011a). Human and rodent aldo-keto reductases from the AKR1B subfamily and their specificity with retinaldehyde. Chem. Biol. Interact. 191, 199-205.

Ruiz, F. X., Porte, S., Gallego, O., Moro, A., Ardevol, A., Del Rio-Espinola, A., Rovira, C., Farres, J., and Pares, X. (2011b). Retinaldehyde is a substrate for human aldo-keto reductase of the 1C subfamily. Biochem. J. 440, 335-344.

Ryan, A. J., Susil, B., Jobling, T. W., and Oehler, M. K. (2005). Endometrial cancer. Cell Tissue Res. 322, 53-61.

Sales, K. J., Boddy, S. C., Williams, A. R. W., Anderson, R. A., and Jabbour, H. N. (2007). F-prostanoid receptor regulation of fibroblast growth factor 2 signaling in endometrial adenocarcinoma cells. Endocrinology 148, 3635-3644.

Sales, K. J., Grant, V., and activate the FP receptor and $\alpha$ Jabbour, H. N. (2008). Prostaglandin E2 and F2 up-regulate cyclooxygenase- 2 expression via the cyclic AMP response element. Mol. Cell. Endocrinol. 285, 51-61.

Sales, K. J., List, T., Boddy, S. C., Williams, A. R. W., Anderson, R. A., Naor, Z., and Jabbour, H. N. (2005). A novel angiogenic role for prostaglandin F2 $\alpha$-FP receptor interaction in human endometria adenocarcinoma. Cancer Res. 65, 7707-7716.

Saraswat, M., Mrudula, T., Kumar, P. U., Suneetha, A., Rao, T. S., Srinivasulu, M., and Reddy, G. B. (2006). Overexpression of aldose reductase in human cancer tissues. Med. Sci. Monit. 12, CR525-CR529.

Sharma, K. K., Lindqvist, A., Zhou, X. J., Auchus, R. J., Penning, T. M., and Andersson, S. (2006). Deoxycorticosterone inactivation by AKR1C3 in human mineralocorticoid target tissues. Mol. Cell. Endocrinol. 248, 79-86.

Shen, Y., Zhong, L., Johnson, S., and Cao, D. (2011). Human aldo-keto reductases 1B1 and 1B10: a comparative study on their enzyme activity toward electrophilic carbonyl compounds. Chem. Biol. Interact. 191, 192-198.
Šmuc, T., Hevir, N., Ribic-Pucelj, M., Husen, B., Thole, H., and Lanišnik Rižner, T. (2009). Disturbed estrogen and progesterone action in ovarian endometriosis. Mol. Cell. Endocrinol. 301, 59-64.

Šmuc, T., and Lanišnik Rižner, T. (2009). Aberrant pre-receptor regulation of estrogen and progesterone action in endometrial cancer. Mol. Cell. Endocrinol. 301, 74-82.

Soda, M., Hu, D., Endo, S., Takemura, M., Li, J., Wada, R., Ifuku, S., Zhao, H. T., El-Kabbani, O., Ohta, S., Yamamura, K., Toyooka, N., Hara, A., Matsunaga, T. (2012). Design, synthesis and evaluation of caffeic acid phenethyl ester-based inhibitors targeting a selectivity pocket in the active site of human aldo-keto reductase 1B10. Eur. J. Med. Chem. $48,321-329$.

Srivastava, S. K., Yadav, U. C., Reddy, A. B., Saxena, A., Tammali, R., Shoeb, M., Ansari, N. H., Bhatnagar, A., Petrash, M. J., Srivastava, S., and Ramana, K. V. (2011). Aldose reductase inhibition suppresses oxidative stress-induced inflammatory disorders. Chem. Biol. Interact. 191, 330-338.

Steckelbroeck, S., Jin, Y., Gopishetty, S., Oyesanmi, B., and Penning, T. M. (2004). Human cytosolic 3 $\alpha$-hydroxysteroid dehydrogenases of the aldo-keto reductase superfamily display significant $3 \beta$-hydroxysteroid dehydrogenase activity: implications for steroid hormone metabolism and action. $J$. Biol. Chem. 279, 10784-10795.

Takemura, M., Endo, S., Matsunaga, T., Soda, M., Zhao, H. T., El-Kabbani, O., Tajima, K., Iinuma, M., and Hara, A. (2011). Selective inhibition of the tumor marker aldoketo reductase family member $1 \mathrm{~B} 10$ by oleanolic acid. J. Nat. Prod. 74, 1201-1206.

Tammali, R., Srivastava, S. K., and Ramana, K. V. (2011). Targeting aldose redutase for the treatment of cancer. Curr. Cancer Drug Targets 11, 560-571.

Tanabe, K., Utsunomiya, H., Tamura, M., Niikura, H., Takano, T., Yoshinaga, K., Nagase, S., Suzuki, T., Ito, K., Matsumoto, M., Hayashi, S., and Yaegashi, N. (2008). Expression of retinoic acid receptors in human endometrialc carcinoma. Cancer Sci. 99, 267-271.

Ueda, M., Hung, Y. C., Chen, J. T., Chiou, S. H., Huang, H. H., Lin, T. Y., Terai, Y., and Chow, K. C. (2006). Infection of human papillomavirus and overexpression of dihydrodiol dehydrogenase in uterine 
cervical cancer. Gynecol. Oncol. 102, 173-181.

Usami, N., Yamamoti, T., Shintani, S., Higaki, Y., Ishikura, S., Katagiri, Y., and Hara, A. (2002). Substrate specificity of human $3(20) \alpha-$ hydroxysteroid dehydrogenase for neurosteroids and its inhibition by benzodiazepines. Biol. Pharm. Bull. $25,441-445$.

Wallace, A. E., Gibson, D. A., Saunders, P. T. K., and Jabbour, H. N. (2010). Inflammatory events in endometrial adenocarcinoma. J. Endocrinol. 206, 141-157.

Wang, C., Yan, R., Luo, D., Watabe, K., Liao, D. F., and Cao, D. (2009). Aldo-keto reductase family $1 \mathrm{mem}$ ber B10 promotes cell survival by regulating lipid synthesis and eliminating carbonyls. J. Biol. Chem. 284, 26742-26748.

Wanichwatanadecha, P., Sirisrimangkorn, S., Kaewprag, J., and Ponglikitmongkol, M. (2012). Transactivation activity of human papillomavirus type $16 \mathrm{E} 16^{\star} \mathrm{I}$ on
AKR1C enhances chemoresistance in cervical cancer cells. J. Gen. Virol. (in press).

Wiebe, J. P. (2006). Progesterone metabolites in breast cancer. Endocr. Relat. Cancer 13, 717-738.

$\mathrm{Wu}$, M. H. (2005). Suppression of matrix metaloproteinase- 9 by prostaglandin E2 in peritoneal macrophages is associated with severity of endometriosis. Am. J. Pathol. 167, 1061-1069.

Wu, M. H., Lu, C. W., Chuang, P. -C., and Tsai, S. -J. (2010). Prostaglandin E2: the master of endometriosis? Exp. Biol. Med. 235, 668-677.

Wu, M. H., Shoji, Y., Chuand, P. C., and Tsai, S. J. (2007). Endometriosis: disease pathophysiology and the role of prostaglandins. Expert. Rev. Molec. Med. 9, 1-19.

Yoshitake, H., Takahashi, M., Ishikawa, H., Nojima, M., Iwanaris,H., Watanabe, A., Aburatani, H., Yoshida, K., Ishi, K., Takamori, K., Ogawa, H., Hamakubo, T., Kodama, T., and Araki, Y. (2007). Aldo-keto reductase family 1 , member B10 in uterine carcinomas: a potential risk factor of recurrence after surgical therapy in cervical cancer. Int. J. Gynecol. Cancer 17, 1300-1306.

Zaitseva, M., Vollenhoven, B. J., and Rogers, P. A. W. (2007). Retinoic acid pathway genes show significantly altered expression in uterine fibroids when compared with normal endometrium. Mol. Hum. Reprod. 13, 577-585.

Zakhaorov, V., Lin, H. K., Azzarello, J., McMeekin, S., Moore, K. N., Penning, T. M., and Fung, K. M. (2010). Suppressed expression of type $23 \alpha$ /type $517 \beta$-hydroxysteroid dehydrogenase (AKR1C3) in endometrial hyperplasia and carcinoma. Int. J. Clin. Exp. Pathol. 3, 608-617.

Zhong, L., Shen, H., Huang, C., Jing, H., and Cao, D. (2011). AKR1B10 induces cell resistance to daunorubicin and idarubicin by reducing C13 ketonic group. Toxicol. Appl. Pharmacol. 255, 40-47.
Conflict of Interest Statement: The author declares that the research was conducted in the absence of any commercial or financial relationships that could be construed as a potential conflict of interest.

Received: 22 December 2011; paper pending published: 05 January 2012; accepted: 19 February 2012; published online: 13 March 2012.

Citation: Rižner TL (2012) Enzymes of the AKR $1 B$ and AKR1C subfamilies and uterine diseases. Front. Pharmacol. 3:34. doi: 10.3389/fphar.2012.00034

This article was submitted to Frontiers in Experimental Pharmacology and Drug Discovery, a specialty of Frontiers in Pharmacology.

Copyright (c) 2012 Rižner. This is an open-access article distributed under the terms of the Creative Commons Attribution Non Commercial License, which permits non-commercial use, distribution, and reproduction in other forums, provided the original authors and source are credited. 